\title{
КРИЗА ПОСТАЧАННЯ ТА КАРТКОВА СИСТЕМА В СРСР КІНЦЯ 1920-х - 1930-х pp.
}

\begin{abstract}
Анотація: У статті досліджується соціально-економічна політика радянської влади кіния 1920-х - 1930-х рр., що спричинила кризу постачання та запровадження карткової системи розподілу. Встановлено, що в історіографії бракує пращь, які б належним чином розкрили ці проблеми. З'ясовано, що кінещь 1920-хрр. означився репресивною, жорсткою економічною політикою держави з обмеження приватного сектора у виробничій і торговельній сферах. Наставали часи централізованого розподілу товарів, що спровокували кризи постачання та запровадження карткової системи. На початку 1930-х рр. така політика породила загострення продовольчої проблеми та масовий голод 1932-1933 рр. Порятунком для населення стала комериійна торгівля, ринки та магазини системи «Торгзін».
\end{abstract}

Ключові слова: СРСР, криза постачання, карткова система, розподіл, голод, спецторгівля

Перехід від тоталітарної моделі економіки до ринкових відносин завжди небезпечний породженням серйозної та системної кризи, що згодом загрожує охопити усі сфери суспільства: економіку, політику, культуру. Сучасне складне і суперечливе соціальноекономічне та політичне становище незалежної України є безпосереднім наслідком її радянського минулого. Тому сьогодні є важливим вивчення досвіду та засвоєння уроків політики радянської держави кінця 1920-х - першої половини 1930-х рр. у сфері постачання населення продуктами харчування, товарами першої необхідності та нормованого розподілу.

Метою статті є актуалізація проблеми соціального забезпечення населення у період радянської модернізації, осмислення державного централізованого постачання, яке стало одним із головних важелів здійснення економічної та соціальної політики. Вибір теми обумовлений недостатнім її вивченням, потребою відтворення історичної правди, абстрагування від історичних міфів і фальсифікацій.

Важливість вивчення окресленої теми визначається постановкою проблеми, яка в історіографії не стала предметом окремого дослідження. У радянській історіографії практично немає праць, в яких автори бралися б за дослідження питань, пов'язаних 3 кризою постачання, запровадження карткової системи або писали про голод як явище, можливе за соціалізму. В їх працях стосовно цих проблем вказувалося на відносний брак товарів і продовольства, і то, у порівнянні з купівельною спроможністю населення. Товарний дефіцит ніколи не досліджувався як невід'ємна риса соціалістичної економіки і системи централізованого розподілу. Радянські історики бачили хронічні кризи надвиробництва

\footnotetext{
* Священко Зінаїда Василівна - доктор історичних наук, професор кафедри всесвітньої історії та методик навчання Уманського державного педагогічного університету імені Павла Тичини ORCID: https://orcid.org/0000-0001-5845-3115; e-mail: szv09@meta.ua
} 
західної економіки, але не бачили хронічних криз постачання у своїй власній. Проблема товарного дефіциту за соціалізму ними подавалася як тимчасові труднощі, пов'язані зі зростанням матеріального благополуччя і грошових доходів населення, списувалася на окремі прорахунки, помилки у плануванні та розподілі, шкідництвом, внутрішніми та зовнішніми катаклізмами (неврожаями, недородами, війною тощо) ${ }^{1}$.

Сучасні дослідники у своїх працях доводять, що ринок і приватне підприємництво, хоча і в дещо деформованому вигляді, існували за планової централізованої економіки². Сфера розподілу і торгівлі, як вторинні або похідні, розглядалися ними у самому загальному вигляді. Кризи, які супроводжують і до сьогодні колишні республіки СРСР, що стали на шлях самостійного розвитку після його розпаду, це невідворотна плата за потужні вихідні деформації, що сформувалися в економіці ще за радянських часів ${ }^{3}$.

Прихід у Росії до влади більшовиків у 1917 р. і поширення їх політики на терени національних окраїн колишньої імперії породив значну кількість не лише політичних, а й соціально-економічних проблем. Однією із ключових постала проблема постачання населення багатомільйонної країни продуктами харчування, паливом і непродовольчими товарами. Запровадження радянською владою політики прискореної націоналізації промислових підприємств та інших суб’єків господарювання періоду «воєнного комунізму» серед негативних для держави результатів означило і необхідність утримувати величезну армію робітників. Соціально-економічні проблеми множилися ще й через те, що у 1920х рр. радянською владою було докладено зусиль для встановлення панування командноадміністративної системи, руйнації створеної НЕПом ринкової структури економіки. Ці роки характеризуються репресивною, жорсткою економічною політикою держави 3 обмеження приватного сектора у виробничій і торговельній сферах. Наставали часи централізованого розподілу товарів, що спровокували кризи постачання та запровадження карткової системи.

Уже 3 кінця 1927 р. кремлівське керівництво розпочало різкий поворот у політиці щодо приватного капіталу та згортання НЕПу. 31928 р. замість оптової торгівлі між підприємствами, відповідно до норм запроваджували державний розподіл матеріальногрошових цінностей. Для боротьби з приватним підприємництвом у торгівлі використовували податковий тиск, державне регулювання цін, високі ціни на транспортування. Для приватної торговельної мережі державні органи перестали відпускати товари. Як наслідок, приватна торгівля вступила у фазу занепаду. У 1927-1928 рр. роздрібна торговельна мережа скоротилася на 22,7\% ${ }^{4}$.

Створилася криза у галузі торгівлі та забезпечення населення необхідними продуктами 5 . У цей час особливо гостро стали проявлятися продовольчі проблеми. 3 грудня 1927 р. черги за хлібом стали звичним явищем. У 1928 р. у провінційних містах черги за

\footnotetext{
${ }^{1}$ Нейман Г.Я. Внутренняя торговля СССР. Москва: Государственное социально-экономическое издательство, 1935. 362 с.; Малофеев А.Н. История ценообразования в СССР (1917-1963). Москва: Мысль, 1964. 438 с.

${ }^{2}$ Осокина Е.А. Иерархия потребления. О жизни людей в условиях сталинского снабжения. 1928-1935. Москва: МГОУ, 1993. $144 \mathrm{c.}$

${ }^{3}$ Ясин Е. Виртуальная экономика в России // Экономика и жизнь. 1999. № 27. С. 4.

${ }^{4}$ Кафенгауз Б. Розничная торговая сеть и предпосылки ее развития // Вопросы торговли. 1929. № 4. С. 64

${ }^{5}$ Крон Ц.М. Частная торговля в СССР. Москва: Труд и книга, 1926. 139 с.
} 
хлібом нараховували до 600 осіб. Населення змушене було стояти у цих чергах по кілька днів. Така ситуація викликала незадоволення, почастішали бунти та страйки 6 .

У 1928-1929 рр. радянська влада запровадила карткову систему торгівлі. У 1928 р. забезпечення населення хлібом за картками розпочалося з України. Рішення про запровадження карткової системи у всесоюзному масштабі було прийнято 14 лютого 1929 р., але через бюрократичні перипетії процес формування та затвердження списків затягнувся аж до осені ${ }^{7}$. Такими заходами намагалися забезпечити населення необхідним мінімумом продуктів харчування. Спочатку запроваджена на хліб, карткова система була поширена на інші дефіцитні продукти - цукор, м'ясо, масло, чай, тощо. До кінця 1929 р. карткова система поширилася майже на всю продовольчу групу товарів, а потім і на промислову, особливо на одяг і взуття.

Постачання тих, хто отримував картки, формувало складну ієрархію категорій і залежало від близькості до центрів промислового виробництва. Переваги у постачанні надавалися особливому та першому спискам, до яких увійшли провідні промислові підприємства Москви, Ленінграда, Донбасу, Баку, Караганди, Східного Сибіру, Далекого Сходу та Уралу. Споживачі особливого і першого списків становили лише 40\% у числі визначених для постачання, але отримали близько 80\% усіх фондів. До другого і третього списків були віднесені малі та непромислові міста, підприємства скло-фарфорової, сірникової, паперової промисловості, комунального господарства, хлібні заводи, дрібні підприємства текстильної промисловості, артілі, типографії тощо. Їх постачання здійснювалося із центральних фондів лише хлібом, цукром, крупою та чаєм за значно нижчими нормами ${ }^{8}$.

Картки першої категорії призначалися для робітників «оборонки», транспорту і зв'язку, інженерів, верхівки армії та флоту. Їм була встановлена норма відпуску хліба у 800 г на день, а членам їх родин - 400 г. Службовці були віднесені до другої категорії постачання й отримували 300 г хліба на день і по 300 г особи, що перебували на їх утриманні. До третьої категорії належали безробітні, пенсіонери, інваліди. Їх норма хліба становила 200 г на день. До «нетрудових елементів» були віднесені торговці, служителі релігійних культів, домогосподарки молодші 56 років. Ці люди були позбавлені права хлібної норми i, щоб вижити, повинні були влаштуватися на роботу ${ }^{9}$.

Замість вільної купівлі-продажу здійснювалося отоварювання за «забірними книжками», через закриті розподільники, робітничі кооперативи, відділи робітничого постачання. Таким чином, з початком 1930-х рр. у товарообороті запанував нормований розподіл, а термін «торгівля» втрачав свій зміст ${ }^{10}$. Нормоване забезпечення продовольством «ходило поряд» 3 криміналом: частими ставали випадки зловживання при розподілі карток, їх підробляли, викрадали, ними спекулювали.

\footnotetext{
${ }^{6}$ «Совершенно секретно»: Лубянка - Сталину о положении в стране (1922-1934 гг.): Сб. док. в 10 т. Т. 6.1928 г. Москва, 2002. С. 323.

${ }^{7}$ Осокина Е.А. За фасадом «сталинского изобилия»: Распределение и рынок в снабжении населения в годы индустриализации. 1927-1941. Москва, 1997. С. 65.

${ }^{8}$ Ibid. C. 91-112.

${ }^{9}$ Трагедия советской деревни. Коллективизация и раскулачивание. Документы и материалы. Т. 4. 1934-1936. Москва: РОССПЭН, 2002. С. 314-320.

${ }^{10}$ Дубровский А.М. Большевизм и торговля (1920-1930-е гг.) // Вестник Брянского государственного университета. 2012. № 2. С. 85.
} 
Недолуга більшовицька політика кінця 1920-х рр. відгукнулася трагедією для всієї країни, особливо постраждало від неї українське селянство. В кінці 1932 р. у країні розпочався масовий голод. У містах вишиковувалися довгі черги за хлібом. Держава не могла вирішити проблему постачання, тому влада рекомендувала керівництву підприємств і організацій шукати можливості та джерела самозабезпечення: проводити самозаготівлі у віддалених регіонах, напряму укладати угоди з колгоспами, організовувати власні кухніїдальні, свинарники, молочнотоварні ферми, городи тощо ${ }^{11}$. Крім того, у зв'язку з наростанням голоду, державою було прийнято низку адміністративно-репресивних заходів, щоб завадити напливу голодних селян у міста та скоротити чисельність контингентів населення, що перебувало на централізованому постачанні. Для цього 27 грудня 1932 р. було прийнято постанову ЦВК і РНК СРСР «Про запровадження єдиної паспортної системи по Союзу РСР і обов'язковій прописці паспортів» ${ }^{12}$. На виконання цієї постанови 3 січня 1933 р. розпочалася паспортизація населення, паралельно з якою здійснювалося масове виселення із великих міст так званих «неблагонадійних» мешканців, яким за різними причинами не видавали паспортів, тим самим позбавляли права на отримання продовольчих карток.

Щоб зняти продовольчий ажіотаж, владою пропагувалися різні форми громадського харчування. У державі сформувалася ціла ієрархія їдалень: на одному і тому ж підприємстві існували різні типи їдалень, які обслуговували робітників, службовців, інженерів. Існували також закриті їдальні для місцевих радянських і партійних працівників, військових, учених, лікарів, вчителів, співробітників правоохоронних органів ${ }^{13}$.

На початку 1930-х рр. в СРСР також було запроваджено систему спецзабезпечення. Поширювалася вона, у першу чергу, на працівників партійно-радянського апарату, а також на персональних пенсіонерів, червоноармійців, колишніх політкаторжан, наукову еліту й інші категорії спеціалістів ${ }^{14}$. Із вжитку зникло слово «магазин», його тепер замінили слова «закритий розподільник», «закритий кооператив», «відділ постачання робітників». Втратило значення слово «продавець», його замінили на слово «різник» - оскільки головним завданням продавця стало нарізання пайків ${ }^{15}$.

Не кращою була і ситуація з постачанням промисловими товарами. До середини 1931 р. нормоване постачання товарів промислової групи запроваджувалося по всій країні на офіційному рівні. Паралельно з нормованим розподілом здійснювалася і комерційна торгівля, діяли колгоспні ринки, а також поширювала свою діяльність і система «Торгзін». Останній варто приділити увагу з огляду на те, що на торгзінівську торгівлю покладали велику надію як держава, так і пересічні громадяни. «Торгзін» (Торгівля з іноземцями) об’єднання магазинів роздрібної торгівлі, які спочатку існували у Москві й інших великих промислових містах і портах СРСР для продажу товарів за валюту іноземним туристам і фахівцям, які працювали на радянських промислових підприємствах ${ }^{16}$.

\footnotetext{
${ }^{11}$ Осокина Е.А. Иерархия потребления... С. 148-152.

${ }^{12}$ Собрание законов и распоряжений рабоче-крестьянского правительства Союза Советских Социалистических Республик. 1932. № 84. Ст. 516.

${ }^{13}$ Малыщева С. Триста граммов хлеба и ватник по ордеру: карточная система в Казани // Родина. 2005. № 8. C. 132.

${ }^{14}$ Осокина Е.А. За фасадом «сталинского изобилия»... С. 92

${ }^{15}$ Осокина Е.А. Иерархия потребления... С. 15.

${ }^{16}$ Осокина Е.А. Золото для индустриализации: «Торгсин». Москва, 2009. С. 19.
} 
Ситуація змінилася, коли з осені 1931 р. магазини «Торгзіну» стали обслуговувати не лише іноземців, але й радянських громадян, які отримали право купувати там товари в обмін на наявні у них валюту та побутове золото (каблучки, сережки, натільні хрестики тощо) $)^{17}$. Постановою від 18 липня 1930 р. Наркомат зовнішньої та внутрішньої торгівлі СРСР створив «Всесоюзне об’єднання по торгівлі з іноземцями на території СРСР» («Торгзін»), яке діяло до 1 лютого 1936 р. і в піковий голодний 1933 р. нараховувало понад 1,5 тис. пунктів торгівлі та прийому від населення цінностей ${ }^{18}$.

Коли країна загрузла у великому будівництві, витрачала гроші на індустріалізацію, своєму населенню видавала продукти по картках, а промтовари за ордерами, магазини «Торгзіну» пропонували товарну розкіш для власників золота чи валюти. У великих містах приміщення магазинів «Торгзін» розташовувалися винятково у центрі. Це були оази достатку на тлі суцільного дефіциту та зубожіння. Для іноземців, на яких спочатку й орієнтувався «Торгзін», його універмаги не були дивиною. За кордоном магазини, наповнені товаром, були звичним явищем. Та й поступалися московські чи київські торгзінівські універмаги за розмахом пропозицій нью-йоркським, лондонським, паризьким закладам торгівлі. Для радянських людей початку 1930-х рр. «Торгзіни» були справжніми палацами торгівлі, які сліпили дзеркальними вітринами та розкішшю товарів, а для когось із них - і музеями, до яких не завжди навіть можна було потрапити, щоб подивитися на крам. У таких магазинах товар був розрахований на вибагливого покупця. Тут були промислові товари експортної якості та делікатеси. Клієнтами таких магазинів ставали чиновники високого рангу, партійні функціонери обкомів і райкомів.

Однак вигляд провінційних магазинів «Торгзін» разюче відрізнявся від тієї ідилічної картини, яку можна було спостерігати у столиці. Вони були плоттю від плоті радянської торгівлі: брудні та темні приміщення з облупленими стінами, моторошна антисанітарія, величезні черги, щоденні бійки, грубість і злодійство продавців, шахрайство приймальників дорогоцінних металів, спекуляція та тотальне обважування покупців, масове псування товарів. Усе це і не тільки, стало буденним явищем у всіх без винятку пунктах торгівлі, як у містах, так і на периферії. Ходовим асортиментом у голодні роки тут були хліб, борошно, крупи, картопля, іноді - цукор, тканини й інші товари повсякденного вжитку.

Візитівкою системи стали довжелезні черги під крамницями, пунктами скуповування цінностей, у торгових залах, біля кас, в яких люди проводили по кілька днів. Часто пункти прийому цінностей розташовувалися у невеликих приміщеннях, де був присутній постійний ажіотаж, сварки та бійки, а недостатня кількість обслуговуючого персоналу лише погіршували ситуацію. Враження клієнтів від відвідування крамниць об'єднання часто було гнітючим. Задоволення від отриманої суми за здані цінності, яка могла врятувати голодну родину, поєднувалося зі смутком назавжди втраченої родинної пам'ятки та образою на часто хамське ставлення співробітників магазинів і приймальних пунктів.

у «Торгзіні» процвітала спекуляція, хабарництво, крадіжки, соціальна сегрегація, п’янство та проституція, «приправлені» радянською специфікою - безгосподарністю, низь-

\footnotetext{
${ }^{17}$ Семенова Ф.Ю. Деятельность Вятского отделения Всесоюзного объединения «Торгсин» (1932-1936 гг.) // Вестник Вятского государственного гуманитарного университета». 2010. № 4 (1). С. 35-40.

${ }^{18}$ Марочко B.I. «Торгсин»: золота ціна життя українських селян у роки голоду (1932-1933) // Український історичний журнал. 2003. №3. С. 91.
} 
кою якістю товарів і послуг, хамством обслуговуючого персоналу, «сімейністю» у формуванні кадрів, постійною присутністю агентів ОДПУ. Самі торгзінівські торгівельні пукти обростали натовпами спекулянтів і злодіїв. На так званому «чорному» ринку можна було придбати все - від хліба, борошна, до модних імпортних товарів, медикаментів тощо $0^{19}$. Перекуплене або вкрадене тут же перепродували за завищеними у десятки разів цінами.

За 1931-1936 рр. діяльності організації громадяни СРСР принесли до «Торгзіну» біля 100 т золота (на теперішні гроші це 11,5 млрд. доларів) і більше 2500 т срібла. За вирахуванням валютних витрат на імпортні товари в розмірі 13,8 млн. крб., чиста валютна виручка «Торгзіну» у ті часи склала 273,4 млн. крб. ${ }^{20}$ Це були колосальні кошти, на які можна було розвивати та будувати потужні радянські підприємства.

Особливо необхідною була комерційна торгівля, ринки та мережа торгзінів для селянства, позбавленців, «соціально чужих», інтелігенції - для тих категорій населення, які стали «зайвими» у новій системі координат радянської держави. Хоча там ціни були вищими у рази, ніж по картках, але це була хоч якась можливість вижити переважній більшості населення СРСР, «залюбленого» радянською владою до смерті.

У жовтні 1934 р. пленум ЦК ВКП(б) прийняв постанову, якою скасовувалася карткова система. 7 грудня 1934 р. була видана постанова РНК СРСР, що ліквідовувала 3 1 січня 1935 р. картки на хліб, крупи та макарони. У вересні 1935 р. було прийнято постанову про скасування карток на м'ясо, цукор, жири та картоплю. 31936 р. скасовувалися картки на промислові товари. Однак, скасування продуктових карток не поліпшило ситуацію. У 1936 р. знову загострилася продовольча проблема. Хлібна криза продовжувала неухильно розвиватися й у низці районів СРСР зимою та навесні 1937 р. і призвела до голоду. Нестача зерна породила і м'ясну проблему, призвела до масового забою худоби. У містах величезні черги стали постійним і звичним явищем. Повсюди ширилися панічні чутки про повторення масового голоду, що призводило до ажіотажного попиту та наростання соціальної напруги. Розпочалося стихійне, не санкціоноване керівництвом країни, регіональне повернення до карткової системи. За вказівками місцевого керівництва, людей прикріпляли до магазинів, створювали закриті розподільники продуктів і товарів на виробництві, встановлювалися норми постачання ${ }^{21}$.

Отже, драматичний сьогоднішній стан нашої економіки свідчить про те, що сучасна криза має глибоке історичне коріння. Це неухильна плата за значні деформації більше як 70-річного розвитку планово-розподільчої системи радянської економіки.

1928-1935 рр. - роки карткового розподілу - об'єктивно означили важливий період української історії, який, без перебільшення, змінив усі сторони життя радянської держави та суспільства. У цей період держава здійснила крутий поворот до принципів «воєнного комунізму». Провідне становище у радянській економічній політиці тепер належало централізованому плануванню, формувався безгрошовий товарообіг. Наслідком цієї ситуації стало одержавлення цін, ліквідація значної частини акціонерних товариств. На початку 1930 р. були ліквідовані біржі та ярмарки, професійна приватна торгівля перестала існувати. Пануюче становище на ринку зайняла споживча кооперація.

\footnotetext{
${ }^{19}$ Центральний державний архів вищих органів влади та управління України. Ф. 4051. Оп. 1. Спр. 71. Арк. 3.

${ }^{20}$ Семенова Ф.Ю. Деятельность Вятского отделения Всесоюзного объединения «Торгсин»... С. 36.

${ }^{21}$ Осокина Е.А. За фасадом «сталинского изобилия»... С. 195-206.
} 
Ціна радянської модернізації виявилася дуже високою. Здійсненням глобальної націоналізації усіх галузей промисловості, банків, транспорту та запровадженням централізації управління було спричинено глибоку соціально-економічну кризу. Продукти харчування, промислові товари та речі широкого вжитку практично зникли з ринку, економічні зв'язки між містом і селом було розірвано. Єдиним джерелом одержання продуктів харчування став відкритий грабіж селян, що спричинило масовий голод 1932-1933 рр. Криза постачання та дефіцит продовольства змусили владу запровадити у 1930-1935 рр. в містах карткову систему на продукти харчування і товари першої необхідності. Рятівним колом для селян та окремих категорій громадян, що потрапили під картковий розподіл, стали комерційна торгівля, колгоспні ринки та торгзінівська мережа.

\section{Zinaida Svyashchenko}

\section{Supply Crisis and Food Rationing in the USSR during the Late 1920s - 1930s}

Abstract: The article deals with the Soviet economic and social policy during the late 1920s - the early 1930s, which caused supply crisis and food rationing. Historiography lacks works revealing the issue in question properly. The article finds that the late 1920s are marked by repressive and harsh economic policies to restrict the private sector in production and trade. Food rationing created a complex hierarchy of categories and depended on the proximity to industrial production centres. In the early 1930s, the normalized rationing prevailed in trade, and the very term «trade» lost its meaning. Such a policy exacerbated the food problem and caused the Great Famine of 1932-33. In this regard, the Soviet government took several administrative and repressive measures to prevent the influx of hungry peasants into the cities and reduce the contingents of the population on a centralized supply. Commercial trade, markets and Torgsin stores became a salvation for the population. The article proves that at a time when the country mired in large-scale construction was financing industrialization and implementing food rationing, Torgsin stores offered commodity luxury for owners of gold or currency. Long lines outside stores, buy-valuables centres, trade halls and cash desks where people could spend days became the signature of the system.

The price of Soviet modernization turned out to be too high. The nationalization of all industries, banks, transport, as well as the introduction of centralized management, had caused a deep socio-economic crisis. Food, manufactured and consumer goods virtually disappeared from the market, and economic ties between urban and rural areas were destroyed.

Keywords: USSR, supply crisis, ration cards, food rationing, famine, special trade 